\title{
ダウンバーストによる建築物の風荷重に関する研究 A Study of Downburst-induced Wind Loading on Buildings
}

\author{
飯田有未*1＼cjkstart植松 康 $^{* 2}$ ガヴァンスキ江梨*3 \\ Yumi IIDA， Yasushi UEMATSU， Eri GAVANSKI
}

\section{SUMMARY}

Downburst produces strong winds near ground and causes severe damage to buildings and people. However, few studies have focused on the downburst flow field and downburst-induced loads on buildings. Thus, the present study attempts to understand the characteristics of downburst and its effects on buildings, based on experiment and numerical simulation. An experimental facility generating a pulsed wall jet has been developed. Large eddy simulation (LES) has also been conducted. First, the unsteady downburst flow field was simulated and compared with the experimental results to validate the Computational Fluid Dynamics (CFD) modeling. Then, a simulation of non-isothermal flow was conducted to understand the characteristics of practical downbursts. Based on the results of experiment and CFD simulation, the characteristics of downburst-induced wind loading on a square building were investigated. Finally, a discussion was made of the evaluation of the design wind loads for downbursts.

key words: downburst, pulsed wall jet simulation, wind force coefficient, CFD, LES

\section{1.はじめに}

近年, 日本において竜巻やダウンバーストなどの突風 災害がしばしば発生し，人的・物的被害を引き起こして いる。気象学分野においては, これら竜巻等突風の発生 予測に関する研究は進んでいるものの, 竜巻やダウンバ 一ス卜内の風の特性や構造物に作用する風荷重に関する
研究は少ない。実際，これらの突風は多くの被害を引き 起こしているが, 発生が局所的で, ある一つの建物が被 害を受ける確率が非常に低いということもあり, 現行の 而風設計では突風による風荷重は一般には考慮されてい ない。

そのような状況より，被害を低減するためには，突風

\footnotetext{
*1 (株) 大林組技術研究所 環境技術研究部

Environmental Engineering Department, Technical Research Institute of Obayashi Corporation

*2 東北大学大学院工学研究科都市・建築学専攻 教授

Professor, Department of Architecture and Building Science, Graduate School of Engineering, Tohoku University *3 東北大学大学院工学研究科都市・建築学専攻 助教

Assistant Professor, Department of Architecture and Building Science, Graduate School of Engineering, Tohoku University （原稿受理年月日：2014年4月 25 日，採用決定年月日：2015年2月23日）
} 
による地表面付近の風の性状および建築物への影響を把 握し, 耐風設計に取り入れることが重要である。本研究 では, これら突風のうち, 我が国ではほとんど研究が行 われていないダウンバーストに注目する。

ダウンバースト(図 1，以下 DB) とは，積乱雲内にある 霞などの降水粒子が上昇気流に打ち勝って狭い範囲に集 中して下降する事により，それに引きずられた周囲の気 流が地表面に衝突し発生する突風を指す。シカゴ大学の Fujita) ${ }^{1}$ が，1975 年 6 月 24 日にニューヨーク，ケネディ空 港で航空機が墜落した原因が積乱雲からの強い下降流で あるということを発見し，それ以来 DB は広く注目され るようになった。DB は風向が突然変化すること，また， 風速のピークが地表面付近で発生する $\left(H j e l m f e l t{ }^{2}\right)$ 実測 において, 地上 $80 \mathrm{~m}$ 地点(平均) でピークが発生)ことなど, 台風や低気圧による強風とは異なる性質をもつ。そのた め建物に作用する風荷重も，一般的な耐風設計で想定さ れている境界層乱流によるものとは異なると考えられる。 そこで本研究では, DB 内の風速分布や DB 内に置かれた 構造物に作用する風圧・風力の特性を把握し, 境界層乱 流と DB の性質および建築物への影響の違いを明確にす ることで，突風を考慮した耐風設計法を提案するための 基礎資料を提供することを目的とする。そのために，ま ず DB シミュレーターを製作し，それを用いた実験と数 值流体計算 $(\mathrm{CFD})$ により, 建築物に作用する風圧, 風力 を把握する。

2. ダウンバーストシミュレーターの製作とそれを用い た実験

\section{1 既往の実験的研究の概要}

DB に対する実験的研究は Fujita3)から始まり，2002 年 には Chay and Letchford ${ }^{4}$ により吹出し口の直径 $D=0.51 \mathrm{~m}$ の大型の噴流装置が用いられ，定常 $\mathrm{DB}$ の風速の鉛直プ ロファイルとキューブに作用する風圧が明らかにされた。 さらに，同実験装置を用いて，Chay and Letchford ${ }^{5)}$ は噴 流装置を動かすことで DB の移動する性質を再現し，ま た Mason ら ${ }^{6}$ はシャッター型の吹き出しを取り付け流れ の可視化を行った。この装置をきっかけに Sengupta ら ${ }^{7)}$ やMcConvill $5^{8)}$ ，Zhang $ら^{99}$ は噴流装置を用いて DB の より詳細な特徴を捉えるため実験的研究を行なった。

我が国においては，佐々ら ${ }^{10)}$ は水槽実験により，長田 $ら^{11)}$ は高密度流体の重力落下により, DB を再現し可視化 を行った。しかし, 建築物への影響の研究は行われてい ない。

そこで本研究では, それらの流れを踏まえ, 東北大学
工学研究科都市・建築学専攻において日本で最大規模の DB シミュレーターの製作を行った。このとき，

・噴流と噴流衝突面の高さの関係の把握すること。

・噴流の強さの影響を把握すること。

・定常 DB と非定常 DB の差を把握する事。

・建物モデルの風荷重を検討すること。 を考慮して装置を製作した。

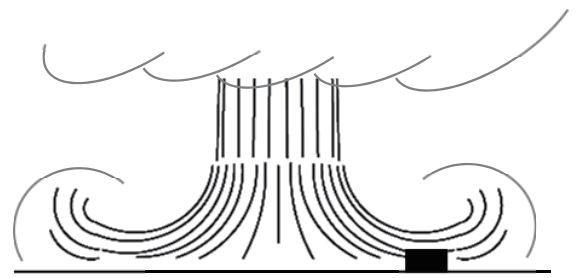

図 1 ダウンバーストの概念図

Fig. 1 Schematic illustration of downburst

\section{2 ダウンバーストシミュレーターの概要}

図 2, 図 3 はDB を再現する噴流装置である。天地を逆 にし，ファンによるジェットが天井板に衝突することで, 地表に衝突する DB の下降噴流を模擬する。天井板は $2 \mathrm{~m} \times 4 \mathrm{~m}$ の集成材を用い，高さは $0.65 \mathrm{~m}$ から $1.25 \mathrm{~m}$ まで $50 \mathrm{~mm}$ ピッチで変えることができる。また噴流を発生さ せるファンはインバータの制御周波数を 0 〜 $60 \mathrm{~Hz}$ まで $1 \mathrm{~Hz}$ ずつ変えることができる。

この送風機の上に取り付けられているシャッター(図 4）は，瞬時に発生し下降する DB の噴流を再現するため の装置である。これはカメラのシャッターの原理を用い て設計した。完全に開くまでの時間(シャッタースピー ド)は 5 段階に変化させることができるが, 本実験では最 速の 0.28 秒を用いる。

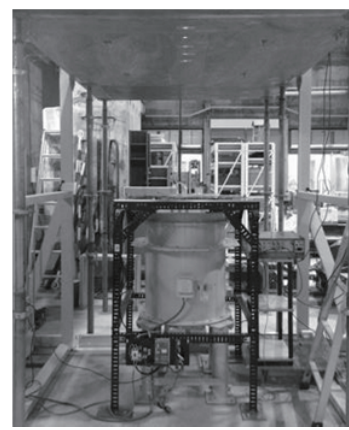

図2 DB シミュレーター

Fig. 2 Downburst simulator 


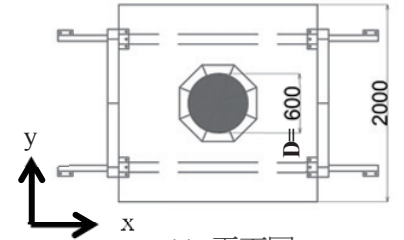

(a) 平面図

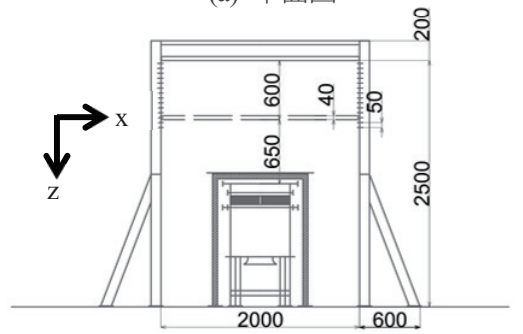

(b) 立面図

図 3 DB シミュレーターの平面・立面図

Fig. 3 Schematic illustration of the DB simulator

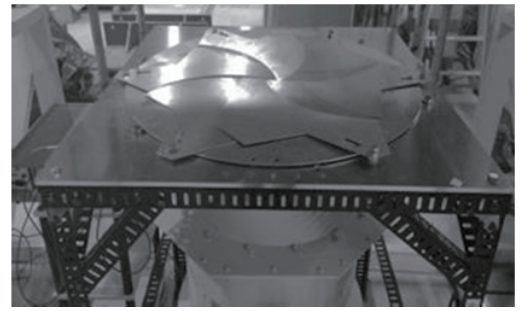

図 4 吹き出し口のシャッター

Fig. 4 A shutter for generating unsteady gust winds

\section{3 実験概要}

実験に際して，ファンから風が吹き続ける噴流を「定 常 DB」, シャッターを用いた瞬間的な噴流を「非定常 DB」 と呼ぶ。また無次元化に用いる長さの基準值としてはフ アンの直径 $D=0.6 \mathrm{~m}$ を用いる。

はじめに, 定常・非定常状態における地表面付近の風 速分布を風速計を用いて計測した。定常 DB の実験にお いては, 天井板中心を $x / D=0$ とし, 外方向へ $x / D=0$ から 1.42 の範囲に計 27 個のサーミスタ風速計のセンサーを設 置し, それらを上下に移動させて測定することで, 各位 置における風速の鉛直プロファイルを求めた(図 5)。ここ で, サーミスタ風速計で計測される風速は支柱方向を除 いた全方向の風速のスカラー量である。また，このサー ミスタ風速計の先端は十分細くブロッケージ効果は大 きくないと考えられる。このときサンプリング周波数は $2 \mathrm{~Hz}$ ，計測時間は 30 秒とした。非定常 DB 実験に関して は，定常 DB 実験と同じ位置に熱線風速計のセンサー(I 型プローブ)を設置し, 測定部を 3 章で示す建物模型の軒
高 $(h / D=0.03)$ に設置し, 風速の時間変化を測定した。この 場合、 $(x, z)$ 面内の風速のスカラー量が測定されること になる。サンプリング周波数は $500 \mathrm{~Hz}$, 計測時間は 60 秒 である。同一条件下で 10 回ずつ測定を行った。

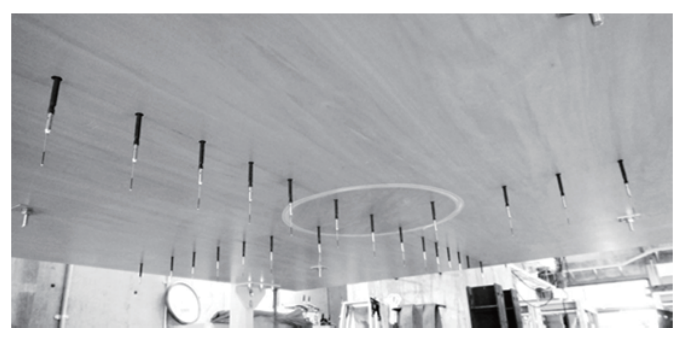

図 5 サーミスタ風速計のセンサーの設置状況

Fig. 5 Arrangement of the sensors of the anemometer

\section{4 結果と考察}

得られた地表面上の定常 DB の風速プロファイルを図 6 に示す。実験で再現した DB の幾何学的縮尺率は $1: 2000$ と仮定している。ここで, 幾何学的縮尺率は Hjelmfelt ${ }^{2)}$ の観測記録より DB の平均吹き出し径が $1500 \mathrm{~m}$ であるこ と, また日本における DB の突風被害の記録(気象庁デー タベース (1975～2013 年) ${ }^{12)}$ ) の被害幅の記録の平均值が $1000 \mathrm{~m}$ 程度であったことより, 実験装置の吹き出し口の 直径 $D=0.6 \mathrm{~m}$, また次章で用いる建物モデルのスケール $(4 \mathrm{~cm} \times 4 \mathrm{~cm} \times 2 \mathrm{~cm})$ との整合性を考慮し 1:2000を仮定した。 縦軸は実スケールの高さを表し, 横軸は最大風速 $U_{\max }$ で 無次元化している。異なる記号は測定点の違いを示し, 比較のため図中に建築基準法による境界層乱流(ABL : 地 表面粗度区分 III ) のプロファイルを載せた $\left(U_{\max }\right.$ は $Z_{\mathrm{G}}=450 \mathrm{~m}$ における $U_{\mathrm{G}}$ を用いた)。この図より $\mathrm{DB}$ に関し ては $x / D \approx 1$ で最大風速を記録し, 風速のプロファイルの 形状は境界層乱流とは大きく異なっていることが分かる。

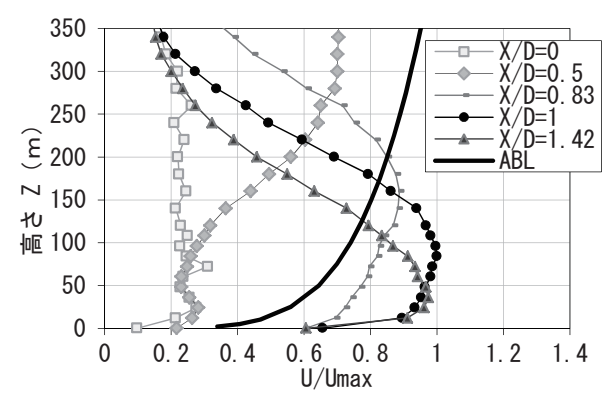

図 6 風速の鉛直プロファイル

Fig. 6 Vertical profile of wind velocity 
図 7 は, 図 6 のプロファイルと Hjelmhelt ${ }^{2)}$ のドップラ ーレーダによる DB の記録(破線) との比較である。縦軸 は最大風速発生高さ $Z_{\max }$ で無次元化した地上高さ, 横軸 は最大風速で無次元化した速度を示す。 $x / D=0.83 \sim 1.42$ の実験值が，実測の最大風速発生時のプロファイルの最 大，最小の範囲に収まっている。これより，本装置が実 測の最大風速発生時の風速分布を概ね再現できているこ とが確認できる。

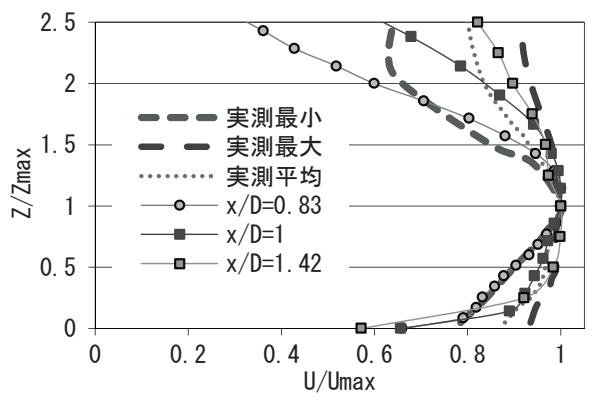

図 7 風速プロファイルに関する実測との比較

Fig. 7 Comparison for normalized velocity profile between experiment and full-scale measurement

図 8 は $x / D=1$, 高さ $h / D=0.03$ 地点の非定常 $\mathrm{DB}$ の風速 の時刻歴を示す。実線は 10 回の計測值の平均を，破線は Fujita ${ }^{1)}$ の実測で観測された最大風速 $67 \mathrm{~m} / \mathrm{s}$ を記録した DB での時刻歴を示している(米国の the Andrew air force base の滑走路で計測された記録)。縦軸・横軸ともに DB の下降速度 (流入風速:噴出口から $100 \mathrm{~mm}$ 離れた地点の中 央部の風速) $V_{j}$ と $\mathrm{DB}$ の径 $D$ で無次元化を行っている。こ れより，実測值と実験值でピークの波とその前後の波の 形状に似た傾向がみられ, 実験装置で再現する非定常 DB は実際の DB の傾向をよく捉えているといえる。その他 の測定点については表 1 に示す点で計測を行った。どの 箇所においても明確なピークが現れ，その後定常状態に 移り変わった。ここで留意すべき点は，定常状態におけ る平均風速が小さい観測点(例えば, $x / D=0.3$ )において, 平均風速に対して大きなピーク值が測定されていること である。

表 1 非定常実験における平均およびピーク風速值

Table 1 Mean and peak velocities

\begin{tabular}{c|c|c|c|c|c}
\hline$x / D$ & 0 & 0.3 & 0.7 & 1 & 1.3 \\
\hline 最大ピーク $(\mathrm{m} / \mathrm{s})$ & 2.72 & 6.12 & 6.63 & 8.47 & 8.01 \\
\hline 平均値 $(\mathrm{m} / \mathrm{s})$ & 0.52 & 1.19 & 2.94 & 4.74 & 4.83 \\
\hline ピーク值/平均値 & 5.21 & 5.16 & 2.26 & 1.79 & 1.66 \\
\hline
\end{tabular}

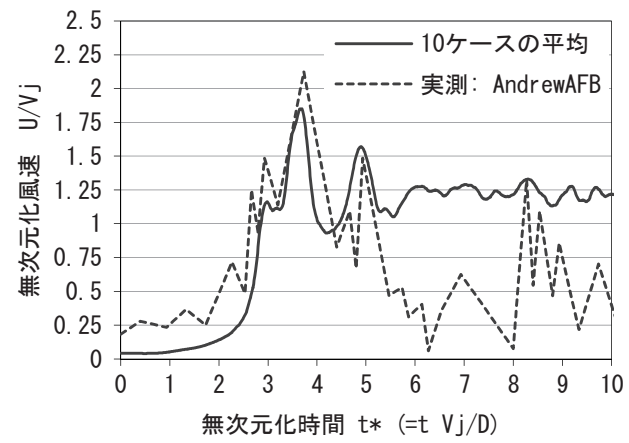

図 8 風速の時刻歴（実測との比較）

Fig. 8 Comparison for time history of wind velocity

between experiment and full-scale measurement

本章では, 流入風速(ファンのインバータの制御周波 数) および天井板の設置位置が, 最大風速発生地点周辺の プロファイルに及ぼす影響を検討した。図 9 および図 10 に流入風速とプロファイルの関係を示した。無次元化は 壁噴流実験の無次元化方法として一般的な方法より, McConvill $5^{8)}$ と $\operatorname{Lin}^{13)}$ と同様の方法で, 最大風速 $U_{\max }$ と 最大風速の半分の風速が発生する高さ $Z_{\max 22}$ を用いた。こ れよりファンの制御周波数 $30 \mathrm{~Hz} \sim 50 \mathrm{~Hz}$ の範囲では，流 入風速の違いによる影響はほぼ見られないことが分かっ た。これと同様に図 11 において天井板から流入口までの 距離(距離 $d$ )の影響を検討したとき，距離 $d$ が $d / D=1.08$ 〜1.83 の場合においては，天井板高さの影響は夕られな かった。一方, 図 12 は, 同じ流入風速と距離 $d$ を用い, $\mathrm{DB}$ 中心と測定箇所の水平距離 $(x / D=1 \sim 1.42)$ の夕を変え た場合のプロファイルを示しており，プロファイルに差 が見られた。これらより，プロファイルが釣鐘型を示す 範囲ではプロファイルは DB 中心と測定箇所の位置関係 にのみに依存することが分かった。またシャッタースピ ードの影響についても検討し, 開くスピードが 0.5 秒以上 の場合, ピークが曖昧になるため以降の解析では 0.5 秒以 下のものを用いることとした。

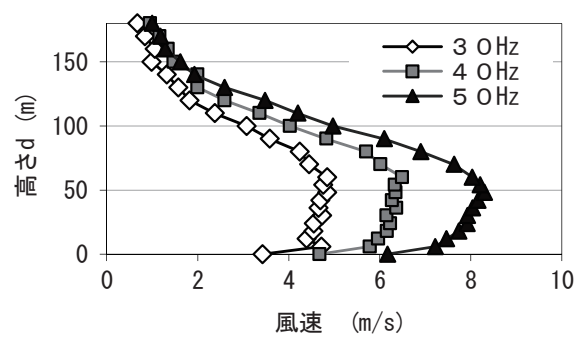

図 9 ファンの制御周波数が風速のプロファイルに 及ぼす影響

Fig. 9 Influence of rotation frequency of fun on velocity profiles 


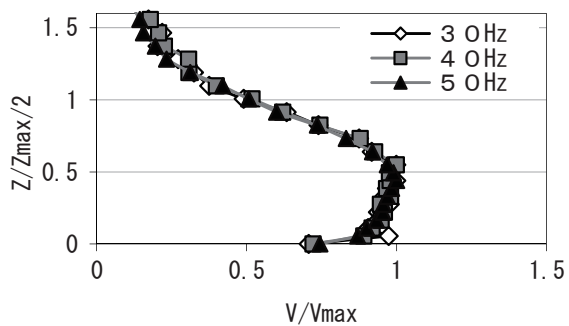

図 10 ファンの制御周波数が無次元化

風速のプロファイルに及ぼす影響

Fig. 10 Influence of rotation frequency of the fun on the profile of normalized wind velocity

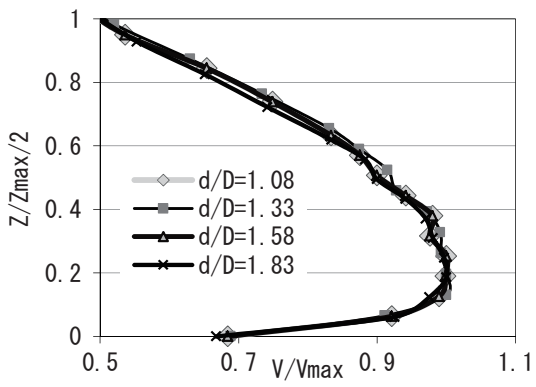

図 11 天井板の設置高さが風速の 無次元化プロファイルに及ぼす影響

Fig. 11 Influence of height of the inlet on the profile of the normalized wind velocity

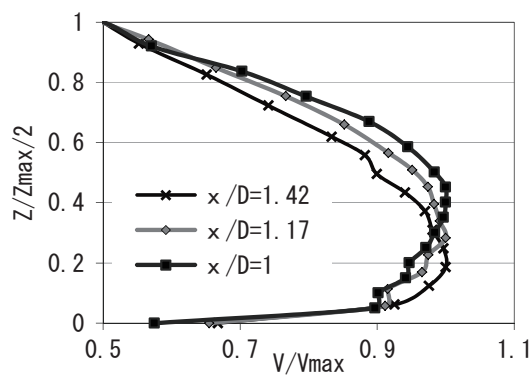

図 $12 \mathrm{DB}$ 中心と測定位置の水平距離が風速

$$
\text { の無次元化プロファイルに及ぼす影響 }
$$

Fig. 12 Influence of the distance between the center of inlet and the measuring point on the profiles of the normalized wind velocity

3.ダウンバーストシミュレーターによる建物に作用す る風圧の測定

\section{1 実験概要}

図 13 に示す建物モデルに対し，前章で製作した DB シ ミュレーターによる気流を作用させて風圧測定を行った。
模型寸法は $4 \mathrm{~cm} \times 4 \mathrm{~cm} \times 2 \mathrm{~cm}$ (実スケール $80 \mathrm{~m} \times 80 \mathrm{~m} \times 40 \mathrm{~m}$ ) で あり，風圧測定点は 44 点設けた(屋根面 16 点, 側面 28 点)。これを天井板中央から $x / D=0,0.33,0.66,1,1.33$ の位 置に設置した。風向 $\theta$ は, 一壁面に正対する風向を $0^{\circ}$ とし, $\theta=0^{\circ}$ と $45^{\circ}$ の 2 種類とした。前章と同様, 定常 DB と非定 常 DB に対し, ファンの制御周波数 $30 \mathrm{~Hz}$ (中心部の流速 $4.02 \mathrm{~m} / \mathrm{s})$ とし, サンプリング周波数 $500 \mathrm{~Hz}$ で 60 秒間計測 した。

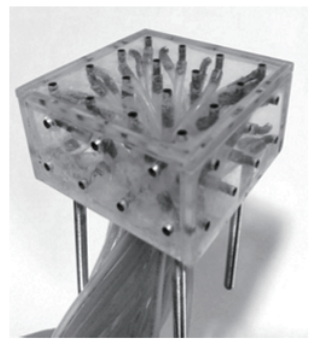

図 13 実験模型
Fig.13 Building model used for experiment

本章では風圧係数の基準化のため, $x / D=1$ 地点の軒高の 定常状態における 30 秒平均風速による速度圧と, 風の影 響のない点での大気压を基準静圧として用いた。 $x, y, z$ 方 向の風力 $\left(F_{x} F_{y} F_{z}\right)$ は外圧を積分することで求め, 軒高の 速度圧と見付面積を用いて無次元化し，風力係数 $\left(C_{F x}\right.$, $C_{F y}, C_{F z}$ ) として表した（図 14 参照)。

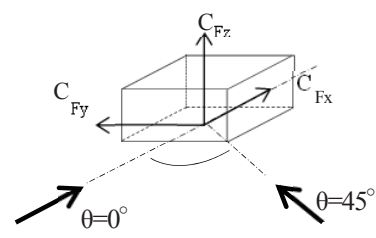

図 14 風力係数の定義

Fig. 14 Definition of wind force coefficients

\section{2 結果と考察}

ここでは風向 $0^{\circ}$ ケースに着目する。 $x / D=1$ 地点の時 刻歴(図 15)より, 風力係数ははじめにピークがありその 後定常状態に移ることが分かる。定常状態においても模 型に周期的な風力が作用しており，この地点にある建物 の屋根部と風上面には大きな負圧と小さな負圧が繰り返 し発生すると考えられる。ピーク值と定常 DB に対する 平均值を比較するため, 図 16 に各測定位置 $x$ における定 常 DB および非定常 DB 下の建物の風力係数を示す。こ こで風向 $0^{\circ}$ のとき, $C_{F y}$ の大きさは小さいため $C_{F x}, C_{F z}$ 
のみを示した。また, 図中の三角は10 回の実験結果の 最大值と最小值を示す。 $C_{F_{X}}$ は常に正の值を示し, ピー ク時には非定常值が定常值の 3 倍近い值を示す。一方, $C_{F z}$ では $x / D=0.33,0.37$ において定常 $\mathrm{DB}$ と非定常 $\mathrm{DB}$ によ る力の向きが逆になり，定常と非定常で大きな差が見ら れる。しかし, $x / D=1$ 以降では常に正の風力(上向き)が建 物に作用する。また両図から概ね $x / D=1$ の位置でピーク 風力係数が最も大きくなることが読夕取れる。これらの 位置で，定常 DB と非定常 DB による風圧分布の差をみ るため, 軒付近の屋根面の一つの測定点 (最大負圧が作用 する点)の最大ピーク值発生時刻における風圧分布を求 めた (条件付きサンプリング)。 $x$ 軸に沿った模型中心断面 内の外圧係数分布を図 17 に示す。ここでは特に風力係数 $C_{F z}$ について定常 DB と非定常 DB の差が見られた $x / D=0.33,1$ の 2 ケースに注目した。

図 17 より， $x / D=0.33$ では屋根の風上側に瞬時に負圧が 作用し, その後正圧が作用している。 $x / D=1$ では風下側屋 根面および後方にも大きな負圧が全体的にかかっている。 これらは DB 気流による建物への影響の大きな特徴であ る。

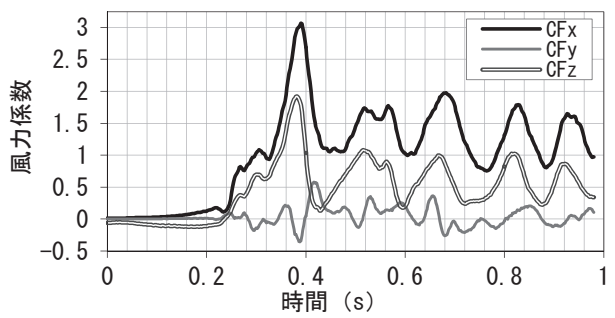

図 15 風力係数の時刻歴

Fig. 15 Time history of wind force coefficients

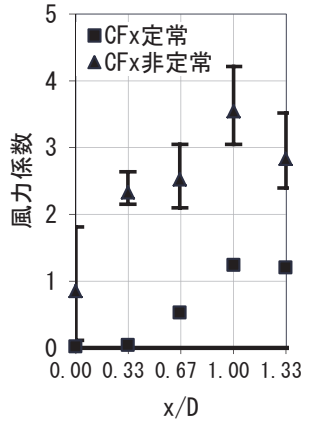

(a) $\mathrm{C}_{\mathrm{Fx}}$

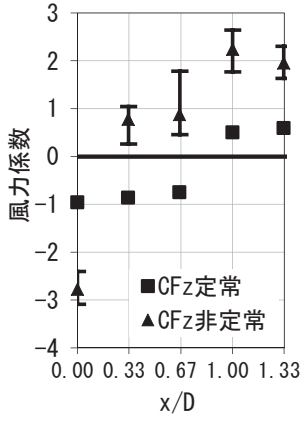

(b) $\mathrm{C}_{\mathrm{Fz}}$
図 16 風力係数の建物位置による変化

Fig. 16 Variation of wind force coefficients with location

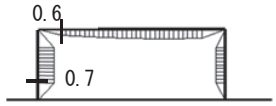

(a) $x / D=0.33$ 定常 $\mathrm{DB}$

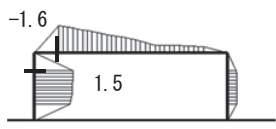

(c) $x / D=1$ 定常 $\mathrm{DB}$

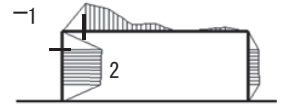

(b) $x / D=0.33$ 非定常 $\mathrm{DB}$

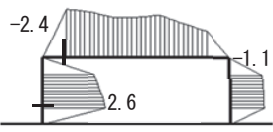

(d) $x / D=1$ 非定常 $\mathrm{DB}$
図 17 断面内の外圧係数分布

(断面左側の壁が風上壁面)

Fig. 17 Instantaneous distribution of wind pressure coefficient on the central cross section

\section{4. 数值解析}

DB 内の流れ場をより詳細に把握するため, 二種類の CFD 解析を行った。まず，実験を模擬した解析 (解析 A) を行い，基本的な解析モデルの検証を行った。次に，DB は冷えた空気塊の落下による現象であり,この現象は実 験での再現が困難なことから，温度变化を流入条件とし た非等温条件での数值解析 (解析 B) も行った。

\section{1 解析条件}

解析にはオープンソースコード OpenFoam2.1.0 14 を用 いた。解析 A,B ともに LES, ダイナミック SGS モデルを 用いた。解析 B においては Navier-Stokes の式にブジネス ク近似による浮力項を加えた式およびエネルギー保存式 を用いた。解析領域, 解析条件を図 18, 図 19 と表 2 に示 す。流入条件は, 解析 $\mathrm{A}$ において妥当な計算時間で計算 を安定させ, クーラン数を 1 以下とするため, 実験(定常 DB）における平均風速の $1 / 3$ の風速による風速分布を用 いた。また解析 BにおいてはAnderson ら ${ }^{15)}$ によって提案, 改良された流入条件 (cooling source) をエネルギー保存式 に加えたもの（式(1)〜(3))を用いた。図 19 にcooling source の温度分布を示す。眓中○で囲んだ部分は低温部を示し ている。

$$
\begin{aligned}
& Q(t, x, y, z)=\left\{\begin{array}{ccc}
g(t) \cos ^{2} \pi R & \text { for } & R<\frac{1}{2} \\
0 & \text { for } & R>\frac{1}{2}
\end{array}\right. \\
& \text { ここで, } \quad R^{2}=\left(\frac{x-x_{0}}{h_{x}}\right)^{2}+\left(\frac{y-y_{0}}{h_{y}}\right)^{2}+\left(\frac{z-z_{0}}{h_{z}}\right)^{2} \\
& \left\{\begin{array}{lr}
g(t)=-A \sin ^{2}(\pi t / 2 \tau) & 0<t<120 \\
g(t)=-A & 120<t<540 \\
g(t)=-A \sin ^{2}(\pi(540-t) / 2 \tau) & 540<t
\end{array}\right.
\end{aligned}
$$


$Q(t, x, y, z)$ : cooling source

$x_{0}, y_{0}, z_{0}$ : cooling source $の$ 座標上の中心位置

ここで, $x_{0}=0_{\mathrm{m}}, \quad y_{0}=0_{\mathrm{m}}, \quad z_{0}=2000_{\mathrm{m}}$

$R$ : cooling source $の$ 中央からの無次元化距離

$h_{x}, h_{y}, h_{z}$ : cooling source $の x, y, z$ 方向の長さ

$$
\text { ここで, } \quad h_{x}=1200_{\mathrm{m}}, h_{y}=1200_{\mathrm{m}}, h_{z}=1800_{\mathrm{m}}
$$

$g(t)$ : 下降噴流強さの時間変化を示すパラメーター

$t:$ 経過時間 $(\mathrm{s})$

$A$ : 下降噴流の強さを示すパラメーター $(A=0.8)$

\section{表 2 解析条件}

Table 2 Analytical condition

\begin{tabular}{|c|c|c|}
\hline & 解析 A & 解析 B \\
\hline 解析領域 & $6 \mathrm{~m} \times 6 \mathrm{~m} \times 1 \mathrm{~m}$ & $8.8 \mathrm{~km} \times 8.8 \mathrm{~km} \times 4.4 \mathrm{~km}$ \\
\hline メッシュ分割 & $5,147,177$ & $4,795,520$ \\
\hline モデル寸法 & $2 \mathrm{~cm} \times 2 \mathrm{~cm} \times 4 \mathrm{~cm}$ & $40 \mathrm{~m} \times 40 \mathrm{~m} \times 80 \mathrm{~m}$ \\
\hline \multirow{3}{*}{ 微分項スキーム } & 発散項： & 混合型 2 次精度中心差分 \\
\hline & 勾配項： & 2 次精度中心差分 \\
\hline & 拡散項： & 2 次精度中心差分 \\
\hline 流入境界 & $\begin{array}{l}\text { 実験值風速分 } \\
\text { 布 }(1 / 3 \text { 風速 })\end{array}$ & $\mathrm{Q}(\mathrm{x}, \mathrm{y}, \mathrm{z}) \quad$ 式(1)(2)(3) \\
\hline 上空・側面 & $\begin{array}{c}p: 0 \\
\text { その他 : 勾配 } 0\end{array}$ & $\begin{array}{c}p: 0 \text { 熱拡散率 : 計算值 } \\
\text { その他 : 勾配 } 0\end{array}$ \\
\hline $\begin{array}{l}\text { 地表面・ } \\
\text { モデル壁面 }\end{array}$ & $\begin{array}{c}U, k: 0 \\
\text { その他: 勾配 } 0\end{array}$ & $\begin{array}{c}U, k \text {, 乱流熱拡散係数: } 0 \\
\text { その他 : 勾配 } 0\end{array}$ \\
\hline 解析アルゴリズム & \multicolumn{2}{|r|}{ PISO 法 } \\
\hline
\end{tabular}

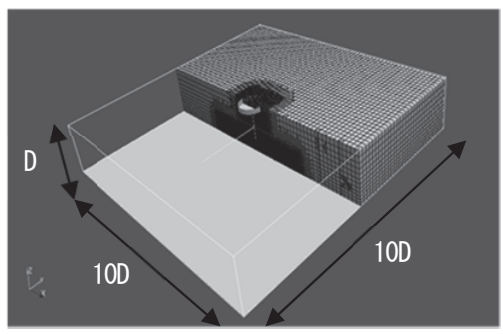

図 18 解析領域 (解析 A)

Fig. 18 Analysis domain (Analysis A)

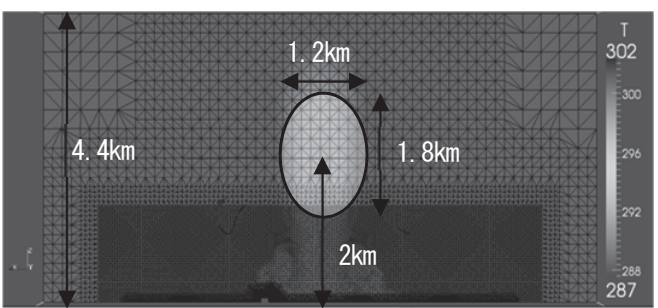

図 19 流入条件(解析 B)

Fig. 19 Analysis domain (Analysis B)

\section{2 結果と考察}

図 20 は図 8 と同様の方法で無次元化した風速の時刻歴 を示し, 図 21 は最大風速 $U_{\max }$ と最大風速の半分の風速が 発生する高さ $Z_{\max 2}$ を用いて無次元化したプロファイル を示す。図 20, 図 21 には DB 実験の結果と解析 A の結 果が示されている。図 20 の時刻歴では立ち上がりからピ 一クが発生するまでの時間とピーク值がほぼ一致してい る。このような傾向は $x / D=1$ だけでなく 1.33 においても 見られた。図 21 の風速のプロファイルを見ると, $x / D=1$, 1.33 における数值解析 $\mathrm{A}$ の定常状態の 1 秒平均の風速プ ロファイルは実験の平均風速プロファイルとよく一致し ている。これらより, 数值解析により $x / D=1$ 近傍の実験 值の風速場が再現できたといえる。

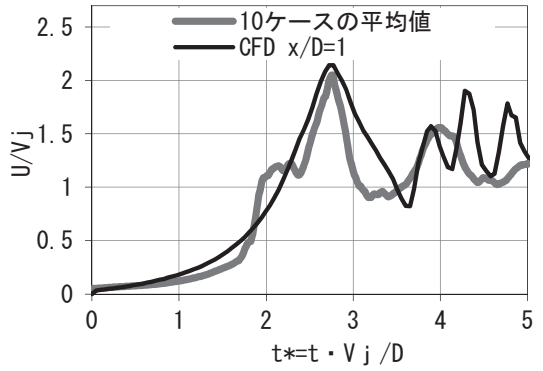

図 20 時刻歴 (解析 A)

Fig. 20 Time history of wind velocity (Analysis A)

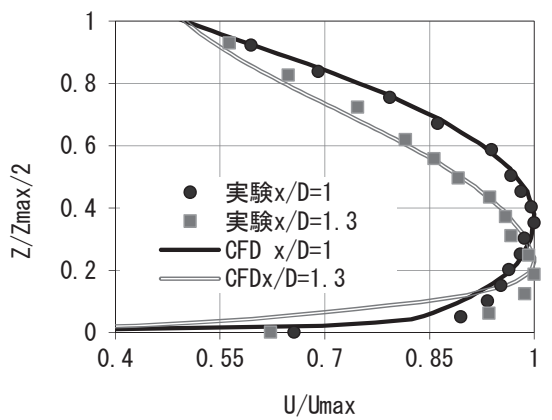

図21 風速プロファイル

Fig. 21Vertical profile of wind velocity (Analysis A)

解析 $\mathrm{B}$ について $x / D=1(D=800 \mathrm{~m})$ のピーク值が発生した 場合の鉛直プロファイル(図 22 : 図 7 と同様の実大 DB と の比較) は, ピーク発生時刻の 3 秒間の平均風速プロファ イルが実測のプロファイルの最大・最小值の範囲に収ま っている。図 23 は図 8 と同じ方法で無次元化した時刻歴 である。ここで無次元化に用いた下降速度 $V_{j}$ は cooling source $の$ 真下, 高度 $1 \mathrm{~km}$ 地点の $\mathrm{DB}$ 中心の風速 $23 \mathrm{~m} / \mathrm{s}$ (計 
算結果の数值) を用いた。直径 $D$ は下降噴流の風速分布 より DB 中心から水平距離 $300 \sim 400 \mathrm{~m}$ で風速 $1 \mathrm{~m} / \mathrm{s}$ 以下と なることより， $\mathrm{DB}$ の直径として $D=800 \mathrm{~m}$ と定義した。 この時刻歴においてピーク值と減衰の傾向が解析 B では よく再現されていることが分かる。これらより, 非等温 解析においても DB の最大風速の性質が再現できている といえる。

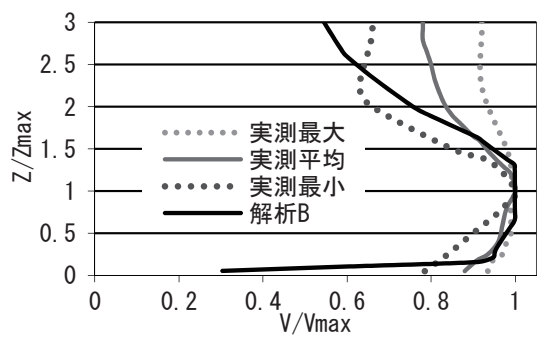

図 22 実測との比較（解析 B）

Fig. 22 Comparison for wind velocity profile between experiment and full-scale measurement

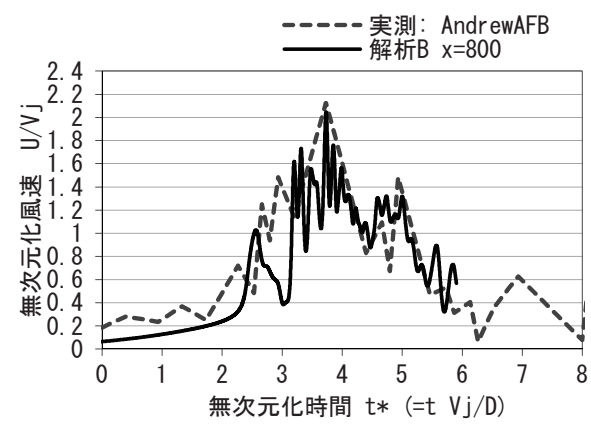

図 23 時刻歴 (解析 B )

Fig. 23 Comparison for time fistory of wind velocity between experiment and full-scale measurement(Analysis B)

$x / D=1$ 地点に建物モデルを設置した場合の，ピーク発 生時刻における風圧分布を比較する。基準化には軒高の 最大ピーク速度圧を用いる (時刻歴は実スケール 3 秒平 均)。実験值(図 24) と解析 $\mathrm{A}$ (図 25 (a) ) を比較すると, 風 上壁面と側面の風圧係数は近い值を示したが，屋根面に おいて風下側に向かい風圧係数が小さくなる傾向は捉え られているものの，屋根面風上側の最大負圧が再現され ていない。これは接近流の乱れが小さいためであり, 解 析 $\mathrm{A}$ の流入条件として平均風速分布を用いたことで，実
験におけるシャッターを用いた非定常な流入風速によっ て発生する乱れが再現できていないためと考えられる。 解析 B においては，流入風速は時間的に変化し，乱れが 大きくなるため, 図 25 (b) に示すように屋根面風上側に大 きな負圧が作用しており, 実験值と屋根面の風上側の傾 向は等しい。その他の壁面の風圧分布は, 実験および解 析 A とも異なった傾向を示しており，これは非等温状態 における建物周りの流れ場が定常的な噴流とは異なるこ とを示唆している。

図 26 は建物周りの風速分布を示す。赤色は分布中の最 大風速を，青色は風速 0 を示す。この図より解析 $\mathrm{A}$ では 建物上空に広く強風域が分布し, 屋根面には流れの剥離 によって渦ができていることが分かる。解析 B において は強風域が地表面に近い部分にとどまり地表面からせり 上がるように強風域が分布している。

風向 0 。

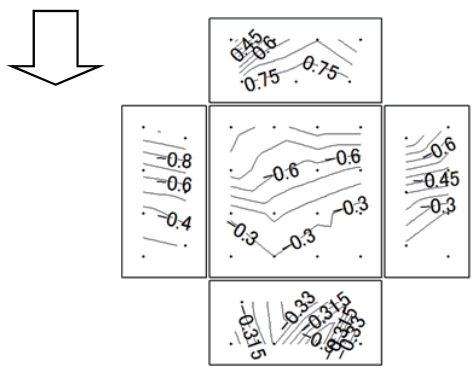

図 24 風圧分布 実験值

Fig. 24 Distribution of wind pressure coefficient obtained from experiment

風向 0

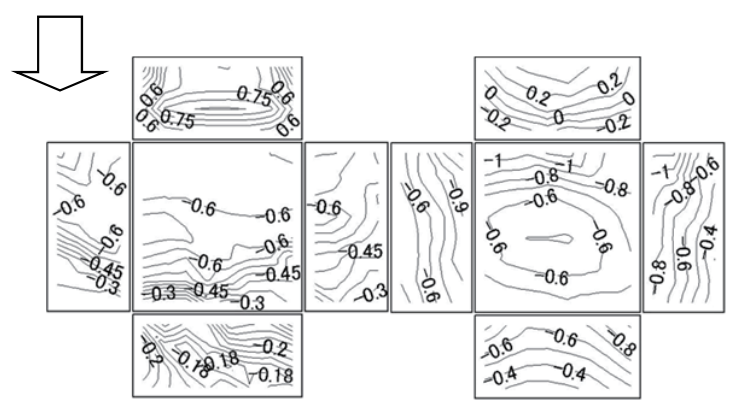

(a)解析 A

(b) 解析 B

図 25 風圧分布 数值計算結果

Fig. 25 Distribution of wind pressure coefficient obtained from CFD 


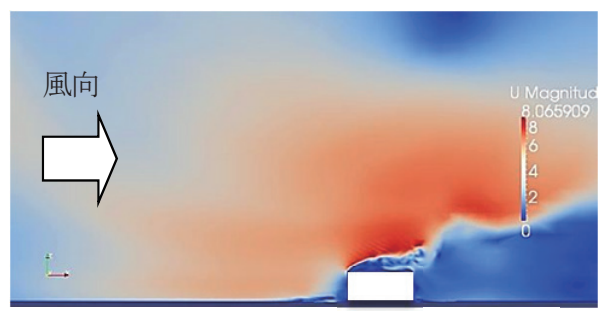

(a) 解析 $\mathrm{A}$

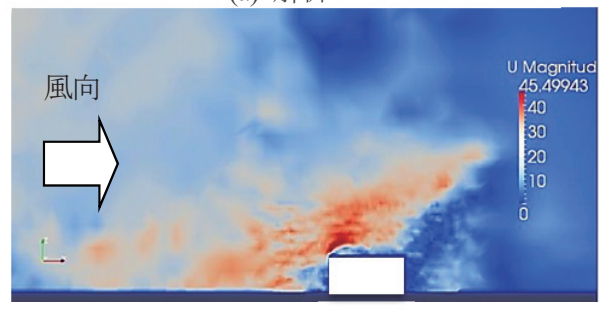

(b) 解析 B

図 26 建物まわりの流れ場

Fig. 26 Flow field around the building

\section{5. 境界層乱流との比較}

\section{1 風洞実験概要}

本章では風洞実験により, 境界層乱流中で建築物に作 用する風力を測定し, DBによる風力との違いを把握する。 風洞実験は, 東北大学工学研究科都市 - 建築学専攻の工 ッフェル型境界層風洞で行った。実験気流は, べき指数 $\alpha \approx 0.21$ の境界層乱流(以下 $\mathrm{ABL}$ ) である。実験模型は 3 章と同様のものを用い, 風向 $0^{\circ}$ と $45^{\circ}$ に対し測定を行った。

\section{2 風圧係数の定義}

一般に風洞実験において風圧係数を定義するとき, 軒 高の平均速度圧と同位置の静圧が用いられる。しかし, DBのような突風の場合, そのような定義では, DB一連 の現象を適切に評価できないため，適した基準化を行う 必要がある。

そこで本研究では式(4)のように風圧係数を定義する。 これは, 米国の設計基準 $\left(\mathrm{ASCE} 7^{16)}\right)$ に代表されるように, 最大瞬間風速 (3 秒平均風速) が突風による風力の評価に 適しているためである。よって，これによって算定され る瞬間速度圧を用い基準を行うこととする。

$$
C_{p}^{*}=\frac{p-p_{s o}}{\hat{q}_{H, x / D=1}}
$$

ここで, $p$ は測定点圧力, $p_{s o}$ は室内大気圧, $\hat{q}_{H, x / D=1}$ は軒 高 $H$ における 3 秒間平均速度圧 (3 秒ガストに基づく速度 圧)である。

\section{3 風洞実験との比較}

$\mathrm{ABL}$ と DB 実験から得られた結果を比較する。図 27
は，風洞実験 $(\mathrm{ABL})$ および DB 実験より得られた模型設 置位置 $x / D=0 \sim 1.33$ における風力係数を比較したものであ る。上段 (a) は定常状態の平均值, 下段 (b) はピーク值を 示す。ここでABL のピーク值は米国の設計基準 ASCE のダーストカーブ 17)を用い、平均速度圧から 3 秒平均 の最大瞬間速度圧に変換し，基準化を行なった值であ る。上段 (a)の定常状態において, $x / D=0 \sim 0.66$ までは建物 に対し下向きに大きな力 (大きな負の $C_{F z}$ ) がかかる点に おいて $\mathrm{ABL}$ の結果と大きく異なっている。 $x / D=1$ 以降で は風上壁面では正圧，屋根面には負圧が作用することは $\mathrm{ABL}$ と同じであるが， $\mathrm{DB}$ による $C_{F z}$ は $\mathrm{ABL}$ の 1/2 程度 である。ピーク值の比較においては, $x / D=1$ 以降では $\mathrm{ABL}$ よりも風上面, 屋根面両方で大きな值を示す。また $x / D=0.33 ， 0.66$ においては，定常 DB では風上面 $C_{F x}$ が小 さな值を示すが, ピーク時には ABL の結果と同等の值と なっている。このようにピーク時 DB の風力係数は, 壁 面もしくは屋根面にABLの值と同等かそれよりも大きな 值を示すことが分かった。

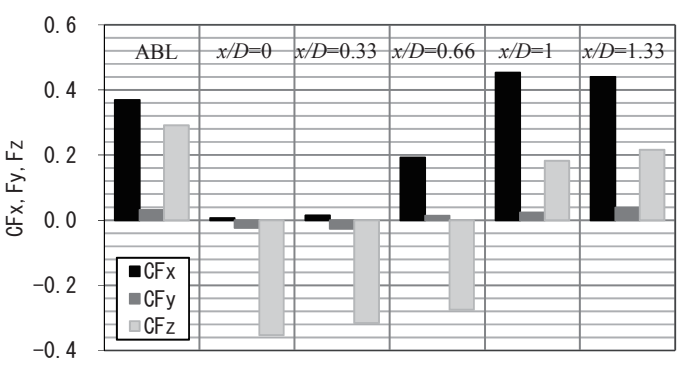

(a) 定常 DB

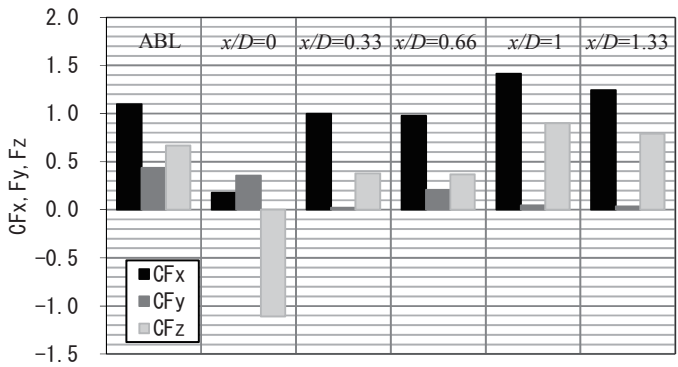

(b) 非定常 DB

図 27 風洞実験と $\mathrm{DB}$ 実験の風力係数(風向 $0^{\circ}$ )

Fig. 27 Comparison for wind force coefficients between $\mathrm{ABL}$ and $\mathrm{DB}$

6.まとめ

製作した DB シミュレーターを用いて実験を行い, DB による建築物の風荷重を検討した。また実験を模擬した 数值解析および，非等温の数值解析を行なった。 
DB に対する而風設計法の提案が今後の課題であるが， 耐風設計を行う上で注意すべき点を, 本研究の結果を踏 まえ挙げる。

まず，DB によって ABL より大きな力が建物に作用す る点が挙げられる。 DB の最大風速は $x / D \approx 1$ で起こり, このときの風力係数はABLでの結果と類似した傾向を示 し, 風力係数の值は $\mathrm{ABL}$ の值の 1.3 倍程度になる。 $x / D$ が 1 以下のときには，下向きの大きな圧力が作用するの で，自重や雪荷重との組み合わせを考えると注意が必要 であり，これにより最大荷重発生点が $x / D \approx 1$ から变わる 場合があるため注意する必要がある。また外装材へのピ 一ク風圧分布を検討した際, 境界層乱流時よりも広い範 囲でピークが発生し, かつ図 15 にあるように周期的に繰 り返し発生するため, この点を今後考慮する必要がある。 今後の課題は, 上記の結果に加え, 可視化による DB の 下降流・水平流・上昇流の把握や DB の移動の性質を考 慮した実験，非等温解析の改良を行い，それらの結果を 用い而風設計法を提案することである。

\section{謝辞}

本研究の一部は，平成 $22 \cdot 23$ 年度科学研究費補助金・挑 戦的萌芽研究「ダウンバーストシミュレータの製作と風 荷重評価の試夕」(研究代表者・植松康)の補助を受け て行われたものである。また本論文は，2013年度日本風 工学会優秀修士論文賞を受賞したものである。

\section{参考文献}

1) Fujita T. Theodore, "Downburst: Microburst and Macroburst", University of Chicago Press, IL, 122pp, (1985)

2) Hjelmfelt R. Mark, "Structure and Life Cycle of Microburst Outflows Observed in Colorado", Journal of Applied Meteorology, Vol. 49, pp. 900-927, (1988)

3) Fujita T. Theodore, "DOWNBURSTS: Meteorological Features and Wind Field Characteristics", Journal of Wind Engineering and Industrial Aerodynamics, Vol. 36, pp. 75-86, (1990)

4) M. T. Chay, C. W. Letchford, "Pressure distributions on a cube in a simulated thunderstorm downburst-Part A: stationary downburst observations", Journal of Wind Engineering and Industrial Aerodynamics, Vol. 90, pp. 711-732, (2002)

5) C. W. Letchford, M. T. Chay, "Pressure distributions on a cube in a simulated thunderstorm downburst. Part B: moving downburst observations", Journal of Wind Engineering and Industrial Aerodynamics, Vol. 90, pp. 733-753, (2002)

6) M. S. Mason, C. W. Letchford, D. L. James, "Pulsed wall jet simulation of a stationary thunderstorm downburst, Part A: Physical structure and flow field characterization", Journal of Wind Engineering and Industrial Aerodynamics, Vol. 90, pp. 711-732, (2002)

7) Anindya Sengupta, Partha P. Sarkar, "Experimental measurement and numerical simulation of an impinging jet with application to thunderstorm microburst winds", Journal of wind Engineering and Industrial Aerodynamics, Vol. 96, pp. 345-365, (2008)

8) McConvill A. C., "The physical simulation of thunderstorm downbursts using an impinging jet", Wind and Structures, Vol. 12, No. 2, pp. 133-149, (2009)

9) Yan Zhang, Partha P. Sarkar, Hui Hu, "Comparison of Microburst-wind Loads on Structures including Scale Effects", The 12th Amiricas Conference on Wind Engineering (12ACWE), June 16-20, (2013)

10) 佐々 浩司, 郷原 建, 木村 安志, 「マイクロバース 卜の模擬実験」, 第 18 回風工学シンポジウム論文集, pp. 229-234, (2004)

11) 長田 泰一, 井出 和人, 小尾 晋之介, 益田 重明, 「地面に衝突する鉛直重力流の統計的性質」，なが れ 24,pp. 67-79, (2005)

12)気象庁,「竜巻等の突風データベース」, http://www.data.jma.go.jp/obd/stats/data/bosai/tornado/, (2015. 2)

13) William E. Lin, "Validation of a novel downdraft outflow simulator: a slot jet wind tunnel", The University of Western Ontario, (2010)

14) OpenFOAM, http://www.openfoam.org/index.php, (2015. 2)

15) Anderson R., Orf L. J. G. and Straka M. J., "A 3-D Model System for Simulating Thunderstorm Microburst Outflows", Meteorol. Atoms. Phys., Vol. 49, pp. 125-131, (1992)

16) ASCE7, "Minimum Design Loads for Buildings and Other Structures : SEI/ASCE 7-05 (Asce Standard No. 7-05)", American Society of Civil Engineer, (2006)

17) ASCE7, "Minimum Design Loads for Buildings and Other Structures: ASCE Standards ASCE/SEI 7-10", American Society of Civil Engineers, p509, (2013) 